\title{
Body Scrub Containing Virgin Coconut Oil, Coffee Grounds (Coffea arabica Linn) and Carbon Active Coconut Shell (Activated Carbon Cocos nucifera L) as a Moisturiser and a Skin Brightener
}

\author{
Desi Eka Putri,, Ratna Djamil,, Faizatun Faizatun ${ }^{1}$
}

\begin{abstract}
Introduction: Virgin Coconut Oil (VCO) contains a lot of medium chain fatty acids. VCO combined with coffee grounds (Coffea arabica Linn) and activated carbon (Activated carbon Cocos nucifera $\mathrm{L}$ ) has the potential to form a preparation that can moisturise and brighten the skin. The purpose of this study was to make cosmetic cleansing preparations containing three natural ingredients.

Methods: This study evaluated the organoleptic body scrub preparations, homogeneity, dispensability and $\mathrm{pH}$ for three different formulations. In vivo test for irritation (oedema and erythema) was carried out on albino rabbits $(n=3)$ for each treatment group. Clinical irritation testing was performed on the forearm of healthy volunteers, 17 - 45 years of age with no history of allergies $(n=30)$. Determination of skin moisture content and melanin index was carried out as a measure of effectiveness.

Results: Organoleptic and homogeneity tests showed that preparations had dark black colour, the distinctive smell of coffee, it was homogeneous, spread ability was in the range of $4 \mathrm{~cm}$ with the $\mathrm{pH}$ at a safe $\mathrm{pH}$ for the skin. Irritation results also did not show any oedema and erythema in in vivo testing. In clinical testing no irritation occurred by testing the body scrub samples. Body scrubs routinely used by volunteers for 2 months increased moisture on the skin as well as brightness $(\mathrm{p}<0.05)$.

Conclusion: Body scrub creams containing VCO, coffee grounds and activated carbon are preparations that have the potential to be cosmetic cleansers.
\end{abstract}

Keywords: Body scrub; Virgin coconut oil; Coffee grounds; Activated carbon.
(1) Faculty of Pharmacy, Universitas Pancasila, South Jakarta, DKI Jakarta, 12630, Indonesia.

Correspondence: DESI EKA PUTRI

E: desiekaputri.audri1@gmail.com

\section{ARTICLE INFO}

Received: 11 February 2021 Revision received: 11 March 2021 Accepted: 13 March 2021

\section{Introduction}

Body scrub is a body care product that can be used to maintain healthy skin. The basic ingredients for body scrubs are always the same, namely as a cleanser. ${ }^{1}$ The basic ingredients for body scrubs are usually made from synthetics as well as from natural ingredients derived from herbal plants. ${ }^{2}$ Herbal plants are one that can be used as safe pharmaceutical preparations and as cosmet- ics that can maintain healthy skin. One of the Indonesian herbal plants that can be used is Virgin Coconut Oil (VCO). The content of saturated fatty acids in VCO can be used as a cosmetic form because it can moisturise the skin and VCO also has a high sun protection factor (SPF). ${ }^{3}$ In addition, other natural ingredients such as coffee grounds can also be used as cosmetic ingredients in skin 
care, because coffee has a high antioxidant content. ${ }^{4}$ Coffee grounds also have a distinctive aroma and rough texture so they can be used to remove dead skin cells. ${ }^{5}$ Coffee grounds also have a long life shelf for 9 months. ${ }^{6}$ Another natural ingredient that can be used is activated charcoal which has detoxification activities. ${ }^{7}$ The body scrubs made in this study were in the form of creams. The cream form has physical stability which can increase the effectiveness of active ingredients on the skin, it is easy to use and to distribute, thus consumers prefer to use cream body scrubs rather than other forms.

\section{Material and Methods}

\section{Materials}

VCO and activated charcoal were obtained from Galenika (Central Java, Indonesia). Coffee grounds were obtained from several coffee shops in the Balaraja area (Tangerang, Indonesia). Cetearyl alcohol and catearate (Cera lanae), phenoxy ethanol, propylene glycol, liquid paraffin, cetyl alcohol, corn starch, polyethoxylated sorbitan and oleic acid (Tween 80), distilled water (Aquadest) were obtained from Brataco (Jakarta, Indonesia).

\section{Methods}

The procedure carried out has been approved by the Health Research Ethics Committee, Muhammadiyah University Prof. Dr. Hamka, with ethical approval number 01 / 19.11 / 0240.

\section{Preparation of Body Scrub}

Body scrubs were made by using the basic ingredient of Cera de lano, using additives phenoxy ethanol, propylene glycol, liquid paraffin, cetyl alcohol, tween 80.

The procedure for making a body scrub was: Cera de lano was mixed over a water bath $\left(70^{\circ} \mathrm{C}\right)$ and mixed until it was homogeneous with other ingredients. For each formula (Formula I, Formula II and Formula III) VCO with distilled water $\left(70^{\circ} \mathrm{C}\right)$ were added and mixed until a white cream base was formed. Coffee grounds, activated charcoal and corn starch were added, then stirred using a homogenizer for about 5 minutes until a body scrub was formed. The composition of the formulas is shown in Table 1.
Table 1: Body scrub formulations containing Virgin coconut oil*, ground coffee and activated carbon

\begin{tabular}{|c|c|c|c|}
\hline \multirow{2}{*}{ Formulation } & \multicolumn{3}{|c|}{ Body Scrub Formula } \\
\hline & $\mathbf{F 1}$ & F2 & F3 \\
\hline Virgin coconut oil (VCO) & 5 & 15 & 25 \\
\hline Activated carbon & 1 & 3 & 5 \\
\hline Coffee grounds & 9 & 7 & 5 \\
\hline $\begin{array}{l}\text { Cera lanae } \\
\text { (mix of cetearyl alcohol and catearat 33) }\end{array}$ & 14 & 14 & 14 \\
\hline Phenoxy ethanol & 0.8 & 0.8 & 0.8 \\
\hline Propylene glycol & 10 & 10 & 10 \\
\hline Liquid paraffin & 5 & 5 & 5 \\
\hline Cetyl alcohol & 2 & 2 & 2 \\
\hline Corn starch & 6 & 6 & 6 \\
\hline Tween 80 & 3 & 3 & 3 \\
\hline Distilled water ad & 100 & 100 & 100 \\
\hline \multicolumn{4}{|c|}{$\begin{array}{l}\text { * Virgin coconut oil (VCO) is coconut oil that is extracted. VCO is made with } \\
\text { copra or dried coconut meat that is removed from the shell and pressed to ex- } \\
\text { tract natural oils. Tween } 80 \text { it is made from polyethoxylated sorbitan (chemical } \\
\text { compounds derived from the dehydration of sugar alcohol) and oleic acid, a } \\
\text { fatty acid found in animal and vegetable fats. }\end{array}$} \\
\hline
\end{tabular}

\section{Evaluation of Body Scrub}

\section{Organoleptic Test}

Organoleptic testing was done visually with the changes in shape, colour and smell of body scrub preparations. The test was carried out for 8 weeks with examination time intervals, namely at week $0,2,4,6$ and 8 at $25^{\circ} \mathrm{C}$.

\section{Homogeneity Test}

To clarify the homogeneity of body scrub preparations, homogeneity testing was carried out using a microscope (Olympus CX23) with magnification (magnification of 40 times). A number of samples were smeared on the glass preparation then the top was covered with a glass preparation. Sample testing was done by taking 3 parts of the body scrub preparation, namely top, middle, bottom. ${ }^{8}$

\section{Spread ability}

Samples $(0.5 \mathrm{~g})$ of each formula were placed in the centre of the Petri plate, then the Petri plate was placed on top. A load of $150 \mathrm{~g}$ was given for 1 minute at $25^{\circ} \mathrm{C}$, after which the diameter of the spread was measured. The diameter of the dispersive power should be in the range $3-5 \mathrm{~cm}{ }^{9}$

\section{pH Evaluation}

The $\mathrm{pH}$ evaluation was carried out using a $\mathrm{pH}$ meter (Mettler Toledo S220). The sample was made as $1 \%$ solution, ie $1 \mathrm{~g}$ sample was dissolved in $100 \mathrm{~mL}$ of distilled water. The acceptable $\mathrm{pH}$ was considered in the range 4.5-6.5. ${ }^{9}$ 


\section{Effectiveness of Body Scrub}

The humidity tester used the Dermalab combo (Cortex) tool. Volunteers with the inclusion criteria were 17 - 45 years old, with healthy skin $(\mathrm{n}=30)$. Non-inclusion criteria were: pregnant and breastfeeding women and/or those that at that time were using drugs that can affect the condition of the skin. It was recommended that volunteers apply the body scrub sample twice a week. Determination of skin moisture content and melanin index was carried out at 0,1 and 2 months after usage.

\section{Pre-Clinic and Clinical Evaluation of Body Scrub}

\section{In Vivo Evaluation of Irritation}

In vivo test for irritation (oedema and erythema) was carried out on albino rabbits $(n=3)$ for each treatment group. The test animals were shaved and then given body scrub samples with their respective formulas (F1, F2 and F3). The sample given was smeared with non-reactive gauze. The degree of irritation was measured after 1, 24, 48 and 72 hours. Measurements were made by giving a score: (0) negative reactions; (1) a little irritation; (2) bordered edge irritation; (3) moderate drainage ( $\pm 1 \mathrm{~mm}$ rising edge); (4) severe irritation (rising edge $> \pm 1 \mathrm{~mm}$ and extending beyond the curb). The score depended on the severity of the skin reactions was produced. ${ }^{10}$

\section{Evaluation of Clinical Irritation}

Clinical irritation testing was performed on the forearm of volunteers $(n=30)$, with an area of 2.5 x $2.5 \mathrm{~cm}$. The criteria for volunteers were: 17 - 45 years of age, healthy, with no history of allergies. After the basting was done, it was left closed for 24 hours, then the observation was carried out for 72 hours. The irritation reaction is characterised by redness, itching and swelling. Measurements were made by giving a score: $(0)$ negative reactions; (1) redness; (2) hives; (3) swelling. ${ }^{11}$

\section{Results}

\section{Preparation and Evaluation Body Scrub}

A body scrub has been successfully made with a cream base. Organoleptic evaluation by conducting visual observations (Figure 1a), showed that the body scrub sample containing VCO, coffee

grounds and activated carbon had a dark black colour with a very sharp distinctive smell of coffee. Homogeneity testing has been carried out under a microscope (Figure 1b). The results of the ob-

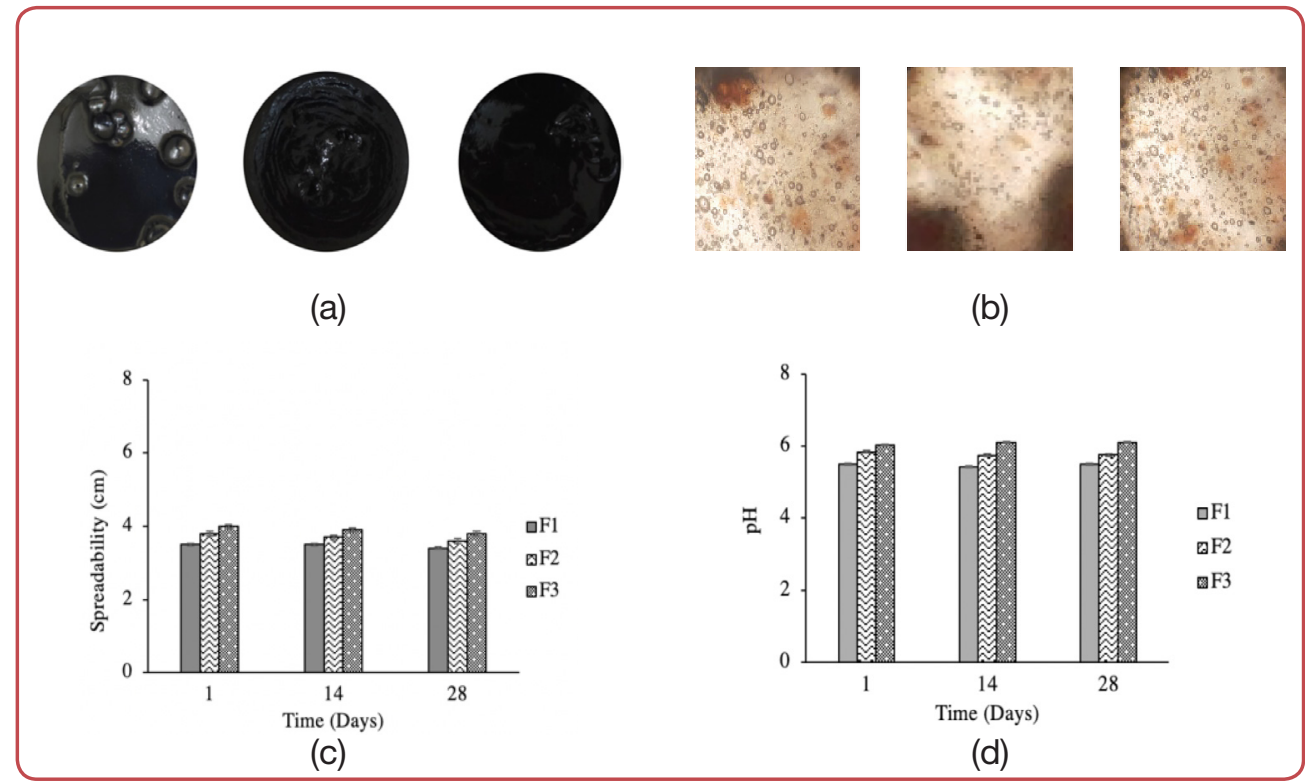

Figure 1: Evaluation of body scrub of VCO, grounded coffee and activated carbon (F1, F2 and F3):

(a) Organoleptic test; (b) Homogeneity test; (c) Spreadability test; (d) $\mathrm{pH}$

${ }^{*}$ F1, F2, F3: different formulation of ingredients 
servations showed that the results of each sample were homogeneous with no lumps. The dispersion test was successfully carried out for 1,14 and 28 days (Figure 1c). The diameter of the F1, F2, and F3 spread ability tests met the requirements because they were in the $3-5 \mathrm{~cm}$ range and there was no significant difference between samples $p>$ 0.05 . Body scrubs had an acceptable $\mathrm{pH}$ and were in a $\mathrm{pH}$ range that is safe for the skin (Figure 1d).

\section{Pre-Clinic and Clinical Evaluation of Body Scrub}

The rabbits were divided into four test groups ( $\mathrm{n}=$ 3) (Figure 2a). In testing with groups formulation 1, 2 and 3 and observations made after 1, 24, 28 and 72 hours, it was shown that body scrubs were safe to use and did not cause oedema or erythema in rabbits. ${ }^{12}$

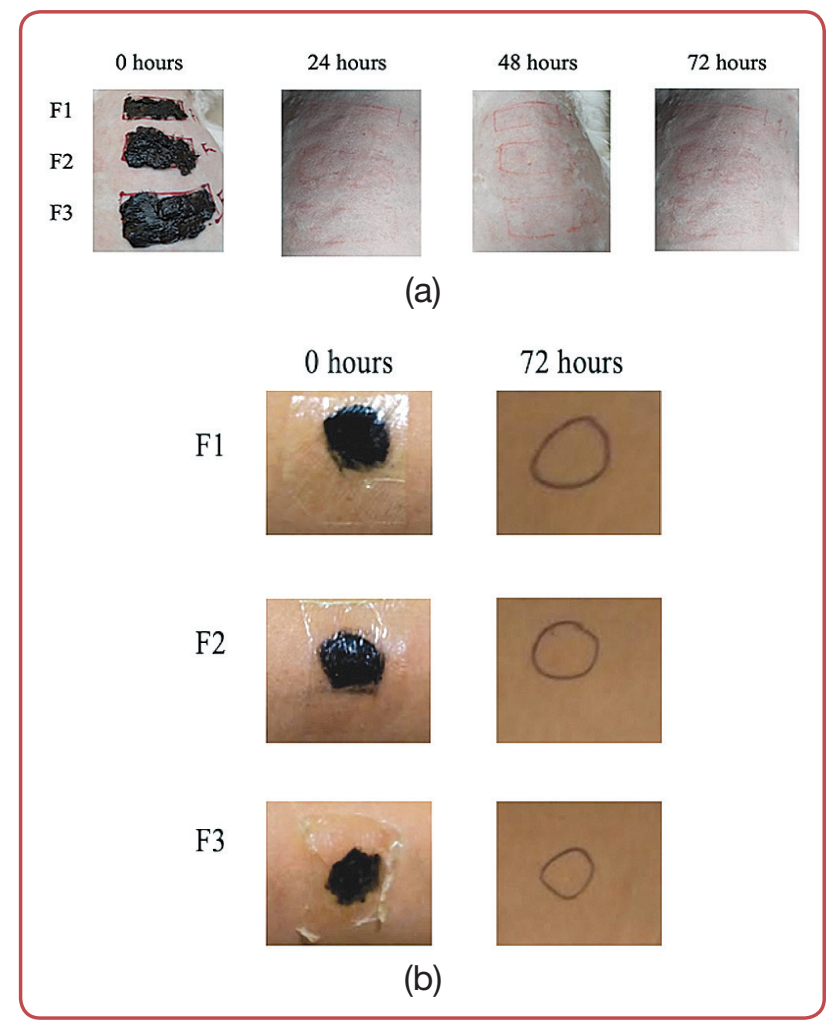

Figure 2: Pre-clinic and clinical evaluation of body scrub of VCO, ground coffee and activated carbon (F1, F2 and F3): (a) Evaluation in vivo of irritation; (b) Evaluation of clinical irritation ${ }^{*}$ F1, F2, F3: different formulation of ingredients

Clinical testing on human skin were performed on three test groups $(n=30)$. Observation on volunteers was carried out for $72 \mathrm{~h}$ (Figure $2 \mathrm{~b}$ ). The results of clinical testing using body scrubs F1, F2 and F3 confirmed negative reactions to the skin of the volunteers, meaning that no irritation occurred by testing the body scrub samples.

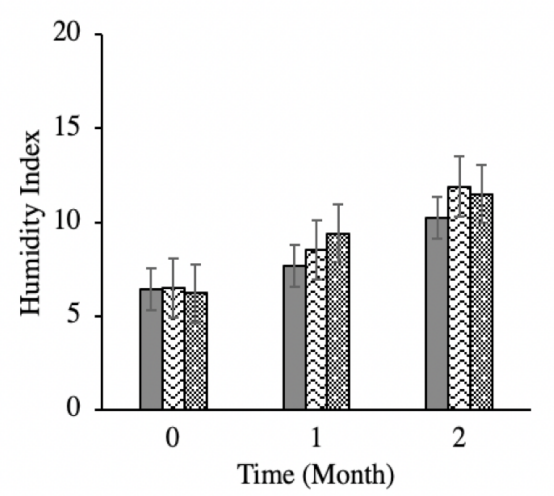

$\square \mathrm{F} 1$

बF2

@ F3

(a)

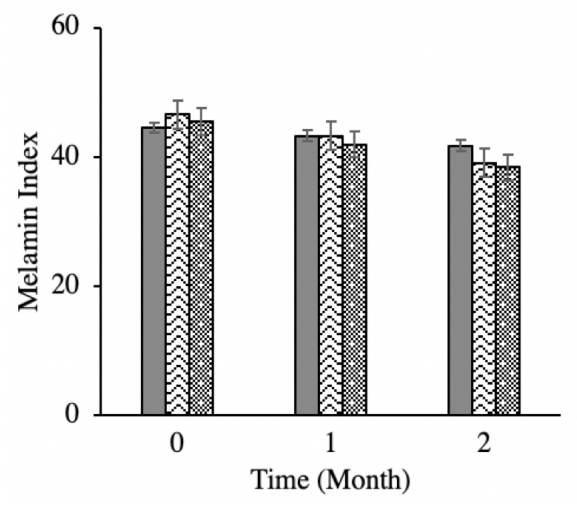

$\square \mathrm{F} 1$

घF2

$\mathrm{aF} 3$

(b)

Figure 3: Effectiveness of Virgin coconut oil body scrub, ground coffee and activated carbon (F1, F2 and F3): (a) Humidity index; (b) Melamine index

${ }^{\star} F 1, F 2, F 3$ : different formulation of ingredients

\section{Effectiveness of Body Scrub}

The effectiveness of VCO body scrubs, coffee grounds and activated carbon by performing moisture testing is shown in Figure 3a. Observations were made before being given treatment and after being given treatment for 0,1 and 2 months. Body scrubs used by volunteers for 2 months routinely increased moisture on the skin with a significance value of $p<0.05$ without significant difference between formulas (Kruskal-Wallis test, $p>0.05$ ). The results of brightness testing on VCO body scrubs, coffee grounds and activated carbon on the skin of volunteers (Figure $3 \mathrm{~b}$ ) showed that there was a significant difference between the time intervals of observation $\mathrm{p}<0.05$.

\section{Discussion}

The results of the observations showed that each sample was homogeneous with no lumps. Homogeneity is influenced by the forming ingredients 
between the water base and the oil base forming a good cream mass. Good spread ability is obtained because the ingredients that make up cream of cetyl alcohol are fatty alcohols which form a white solid, such as wax, and catereat is an oil/water $(\mathrm{O} / \mathrm{W})$ base which can form a dense and oily mass like butter.

In tests on days 1,14 and 28 , it was found that there was no significant change in $\mathrm{pH}$ in body scrub samples during the storage period $\mathrm{p}>0.05$. The $\mathrm{pH}$ was safe because catereat base material can form a stable $\mathrm{pH}$ in cosmetic preparations. In addition, the content of activated carbon has a water content of $15 \%$ which can increase the $\mathrm{pH}$ in the skin $\mathrm{pH}$ range $(4.5-6.5)$. Also, evaluation of body scrub preparations obtained good results because VCO has the stability for 48 days, where this stability affects homogeneity/appearance, changes in colour, odour, consistency, $\mathrm{pH}$ and viscosity. ${ }^{13}$

Body scrub preparations with VCO active substances, coffee grounds and activated carbon are safe for use on human skin. ${ }^{14}$ The absence of irritation to the skin is also influenced by the physical and chemical properties of VCO which is very good for use as a moisturiser on the skin. Coconut dregs which have the ability as an antioxidants are also able to absorb into the skin layer, where antioxidants can neutralise free radicals. ${ }^{15,16}$

Comparative data between the three formulas did not have a significant difference in the increase in skin brightness in the volunteers ( $p>$ $0.05)$. The effectiveness of body scrub is supported by the presence of antioxidant abilities in coffee grounds which can increase collagen productivity in the skin. The antioxidant content in skin care products, particularly vitamin $\mathrm{C}$, has been shown to be beneficial in reducing melanin pigmentation in the skin.

\section{References}

1. Ulfa M, Khairi N, Maryam F. Formulasi dan evaluasi fisik krim body scrub dari ekstrak teh hitam (Camellia sinensis), Variasi Konsentrasi Emulgator Span-Tween 60. J Farm 2016;4(4). Indonesian. doi:https://doi. org/10.24252/.v4i4.2257.

\section{Conclusion}

VCO body scrub with coffee grounds and activated carbon with various formulas 1, 2 and 3 were successfully carried out with several evaluations confirmed. The difference in concentration in each formula did not affect the evaluation results of body scrubs. The $\mathrm{pH}$ of each formula was still in the safe range for the skin. The $\mathrm{pH}$ results were correlated with in vivo testing as well as clinical irritation testing carried out for $72 \mathrm{~h}$ without oedema and erythema in the skin of the volunteers. The results of testing the effectiveness of moisture and brightness on VCO body scrubs with coffee grounds and activated carbon found: the longer the scrub was used, the more moisturised and brighter volunteer skin was.

\section{Acknowledgements}

1. Especially for my husband Muji Harja and Ananda Mufida Hazimah Amudria (Audri) who have given love, attention, encouragement, permission, blessings and have accompanied them during their education until completing this thesis.

2. Both parents and parents-in-law with great love and blessings so that the author can achieve this goal.

3. All parties who have helped the completion of this thesis who cannot be named individually.

4. Thank you to those who have contributed to the research and writing of this journal.

\section{Conflict of interest}

None.

2. Ervina A, Santoso J, Prasetyo BF, Setyaningsih I, Tarman K. Formulation and characterization of body scrub using marine alga Halimeda macroloba, chitosan and konjac flour. IOP Conf Ser Earth Environ Sci 2020;414(1). doi:10.1088/1755-1315/414/1/012004. 
3. Mu'awanah IAU, Setiaji B, Syoufian A. Pengaruh konsentrasi Virgin Coconut Oil (VCO) terhadap stabilitas emulsi kosmetik dan nilai Sun Protection Factor (SPF). J Math Nat Sci 2014;24(1). Indonesian.

4. Hertina TN, Dwiyanti S. Pemanfaatan ampas kedelai putih dan ampas kopi dengan perbandingan berbeda dalam pembuatan lulur traditional untuk perawatan tubuh. J Tata Rias 2013;2(3):70-77. Indonesian.

5. Desyntia D. Sehat Dengan Secangkir Kopi. Surabaya; 2012. Indonesian.

6. Ningsi S, Nonci FYN, Sam R. Formulasi sediaan lulur krim ampas kedelai putih dan ampas kopi arabika. J Farm 2015;3(1). Indonesian.

7. Lestari U, Farid F, Sari PM. Formulasi dan uji sifat fisik lulur body scrub arang aktif dari cangkang sawit (Elaeis Guineensis Jacg) sebagai Detoksifikasi. J Sains dan Teknol Farm 2017;19(1). Indonesian.

8. Zhang J-T, Huang S-W, Zhuo R-X. Preparation and characterization of novel temperature sensitive poly (n-isopropylacrylamide-co-acryloyl beta-cyclodextrin) hydrogels with fast shrinking kinetics. Macromol Chem Phys 2004;205(1):107-113. Indonesian.

9. Fitriani L, Afifah, Ismed F, Bakhtiar A. Hydrogel formulation of usnic acid and antibacterial activity test against propionibacterium acne. Sci Pharm 2018;87(1):1. doi:10.3390/scipharm87010001.
10. Peraturan Kepala Badan Pengawasan Obat Dan Makanan Tentang Pedoman Uji Toksisitas Non Klinik Secara In Vivo. Jakarta; 2014. Indonesian.

11. Tranggono RI. Ilmu Pengetahuan Kosmetik. Djajadisas. PT Gramedia Pusat Utama; 2007. Indonesian.

12. Widiarti SIM. Formulasi dan uji sifat fisik lulur serbuk kulit buah manggis (Garcinia Mangostana Linn) dan serbuk kopi (Coffea Arabica Linn) untuk perawatan tubuh formulation. J Kesehat Al-Irsyad. 2017;X(1). Indonesian.

13. Padmadisastra Y, Widodo S, Syaugi A. Pembuatan basis krim VCO (Virgin Coconut Oil) menggunakan microwave oven. IOCD Int Symp Semin Indones Med Plants 2007;XXXi. Indonesian.

14. Hui SBL, Susilohadi G. Structure analysis of health-related indicators of the elderly at home with a focus on subjective health. Procedia - Soc Behav Sci 2014;2(1).

15. Alamsyah N, Djamil R, Rahmat D. Antioxidant activity of combination banana peel (musa paradisiaca) and watermelon rind (citrullus vulgaris) extract in lotion dosage form. Asian J Pharm Clin Res 2016;9(9):300. doi:10.22159/ajpcr.2016.v9s3.14926.

16. Djamil R, Wahyudi P, Wahono SMH. Antioxidant activity flavonoid from Andredera cordifolia (TEN) Steenis leaves. Int Res J Pharm 2012;3(9):241-3. 